Global Conferences Series:

Social Sciences, Education and Humanities (GCSSSEH), Volume 3, 2019

The $1^{\text {st }}$ International Conference on Education, Social Sciences and Humanities

DOI: https://doi.org/10.326/hum0216

\title{
EXO OLO TASK Learning Model: What Should Students Do in The Class?
}

\author{
Nofrion $^{1(*)}$, Rahmanelli ${ }^{2}$, Yurni Suasti ${ }^{3}$, Khairani ${ }^{4}$, Bayu Wijayanto ${ }^{5}$, Bigharta Bekti \\ Susetyo ${ }^{6}$, Rery Novio ${ }^{7}$, Surtani ${ }^{8}$ \\ 1,2,3,4,5,6,7,8Universitas Negeri Padang, Indonesia \\ $\bowtie$ dion_geografi@yahoo.com
}

\begin{abstract}
The purpose of this article is to describe the EXO OLO TASK Learning Model as a learning model that can develop variative and creative learning activities. This model is also relevant to the 21st century learning skills and Curriculum 2013 learning. This article is a conceptual idea based on underlying theories and concepts and supported by empirical data because it was developed in dissertation research using the ADDIE development model. This model has four syntaxes, namely, 1) strengthening concepts, 2) EXO TASK, 3) OLO TASK, 4) Reflection. The advantages of this learning model are: 1) can develop creativity, critical thinking, communication and collaboration and higherorder thinking skills of students as the core of 21st century learning, 2) can develop higher quality learning activities and more complete learning experiences, 3) the multilevel and challenging questions is the trigger for the expected learning activity. The application of this learning model can help teachers to answer basic questions about 21st century learning that is "what should students do at class?"
\end{abstract}

Keywords: EXO OLO TASK Learning Model, HOTS, learning activity, learning skills

\section{Introduction}

Learning is the process of teaching someone to be better in aspects of knowledge, attitudes and skills. In Law number 20 of 2003, section 1 article 20 states that learning is the process of interaction between students and teachers and learning resources in a learning environment. From this definition, at least there are four learning keywords, namely; 1) interaction, 2) learning resources, 3) learning environment, 4) teachers and students. Interaction refers to learning activities and learning experiences, and teachers and students are the main actors of learning. In the context of the Curriculum 2013, learning must be based on 14 learning principles which include student-centered learning; anyone is a teacher, and various learning resources. Learning must also be carried out in a pleasant, interactive, challenging, inspirational, participatory atmosphere (Permendikbud number 22 on Process Standards).

At the global level, learning refers to the 21st century learning framework, known as P21, which includes; 1) learning and innovation skills, 2) information, media and technology skills, 3) life and career skills. Point 1 includes 1) creativity and innovation, 2) critical thinking and problem solving, 3) communication, 4) collaboration (Marzano \& Heflebower, 2012; Bialik \& Fadel, 2015). In addition, it must also be in line with the development of the Industrial Revolution 4.0 era by integrating three

Copyright (C) 2019, the Authors. Published by Redwhite Press.

Page | 188

This is an open access article under the CC BY-NC license

(http://creativecommons.org/licenses/by-nc/4.0). 
new literacy that is; 1) data, 2) technology and 3) humans (Aoun, 2017) in learning. All of these developments have been adopted into the 2013 curriculum and the Indonesian Partnership for 21st Century Skill Standard/ IP-21CSS known as 4K and HOTS Learning (Widana, 2017; Nofrion, 2018).

However, the fact is that there are still many conventional and teacher-centered learning practices in the classroom, minimal dialogue and interaction, collaboration and less challenging (Nofrion, 2019). If this condition is allowed, it will obstruct the achievement of learning goals including Geography subjects as one of the Key Subjects and essential themes in 21st century learning (CCR, 2015). This is what underlies the development of the EXO OLO TASK learning model as a learning model based on the constructivist paradigm and collaborative learning. The application of the right model can optimize the development of students' potential as a learner because with the learning model the potential of students as learners can be developed (Joyce \& Weil, 2011). The learning model will direct effective learning activities both from the teacher's and students' side and through the application of the model, it can be explained what activities can be done in the classroom so that learning objectives can be achieved.

The EXO OLO TASK learning model focuses on providing space for students to learn with varied conditions such as individual, in pairs or in groups learning. By managing learning activities like that it is expected that students can search, shape and construct more knowledge. In accordance with the 21st century learning paradigm, learning like this is expected to be able to develop Higher Order Thinking Skills (HOTS) among students.

\section{Review of Related Literature}

EXO - OLO TASK Learning Model is based on collaborative nuance of contructivistic learning theory on Geography learning which aims to develop students' higher order thinking skills through the arrangement of learning and collaboration activities triggered by two types of questions that are EXO TASK and OLO TASK. This learning model consists of four syntaxes, namely: 1) Strengthening Concepts, 2) Questions C1 - C3 or EXO TASK, 3) Questions C4 - C6 or OLO TASK and 4) reflection of the learning process (Nofrion, 2017; Nofrion, 2018). In more detail, the profile of the operational components of the EXO OLO TASK Learning Model can be studied through the following picture: 


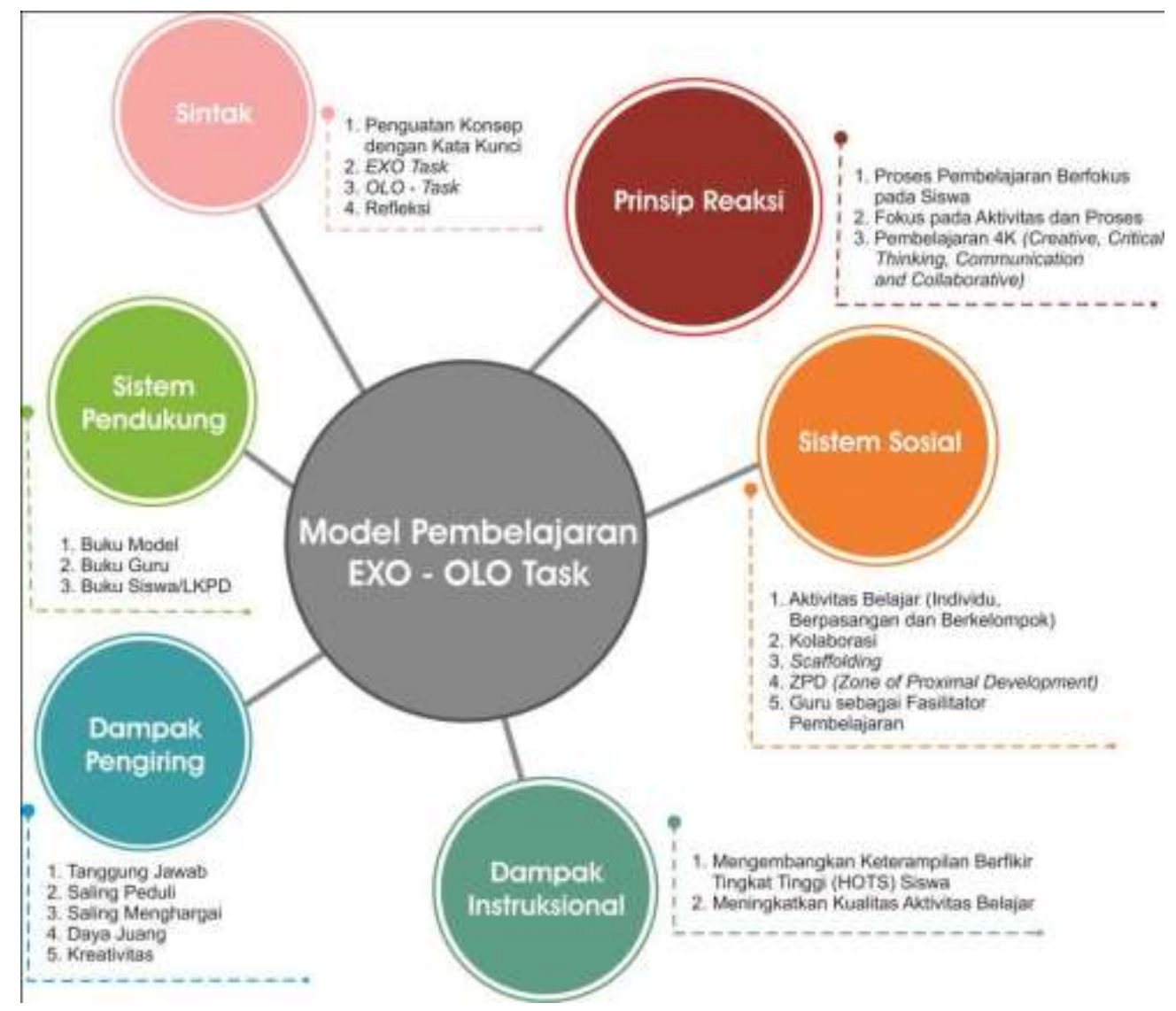

Picture 1: Profile of EXO OLO TASK Learning Model

The main theories underlying this learning model are:

Constructivistic Learning Theory.

Constructivistic learning theory is a variation of cognitive learning theory based on the principle that individuals construct understanding and knowledge (Ansyar, 2015), actively process acquired knowledge (Brandt \& Tyler, 2007; Schunck, 2012). Learning is not a process of pouring information into students (spoon feeding) but students build meaningful information for themselves (Slavin, 1994). Constructivist learning encourages students to explore knowledge through an activity called the "process learning" strategy where students are helped to process information so that it becomes meaningful knowledge and then applies what has been obtained to solve problems encountered called "generative learning" (Slavin; 1994, Jonassen; 1985, Wittrock; 1974, Kemp et al; 1994). Constructivistic emphasizes the active role of students in building understanding and giving meaning to information and events they experienced (Woolfolk, 2005) and the need for difficult questions as a way to encourage students to study as long as it is still in ZPD (Vygotsky, 1978; Sato, 2012).

Constructivist learning provides opportunities for students to discover, assimilate, and apply ideas so that they have a strategy to transform knowledge. It means that the main role is played by students (Ornstein \& Hunkins, 2013), the need for "disequilibrium" old knowledge with the new one if the old one is invalid (Slavin, 1994). Constructivistic learning can begin with complex questions so that students are able to express their full potential and then the teacher or other party gives assistance called ladders. Slavin (1994) explains "Teachers can give students ladders that lead to higher understanding, yet the students themselves must be climb these ladders." In constructivist, the teacher has more role to help students transform knowledge rather than communicate knowledge (Richey et al, 2011). 


\section{Higher-Order Thinking Skills/HOTS}

The development of higher-order thinking skills/ HOTS is a must in the practice of 21st century learning and students must have it in modern life (Widana, 2017; Nofrion, 2018). The Australian Council for Educational Research (ACER) states that higher-order thinking skills are a process of: analyzing, reflecting, arguing (reasoning), applying concepts to different situations, composing, creating (Widana, 2017). Stein \& Lane (1996) defines HOTS as the use of complex thinking and uses different approaches, ability to complete tasks with many solutions (Senk et al., 1997 in Lewy et al., 2009) and requires effort to find structures or solutions (Resnick, 1987; Splitter, 1991 in Lewy et al., 2009).

Brookhart (2010) states that HOTS is 1) analysis, evaluation and creation, 2) logical reasoning, 3) consideration and critical thinking, 4) problem solving and creative thinking.

Higher-order thinking skills can be defined as the potential of one's mind that can be used to interpret, analyze and manipulate information (Mohamed, 2006; Ea, Chang, \& Tan, 2005), the highest level in cognitive processes and can occur when someone gets a new information, stores it in memory and compile and then use that information to achieve a goal or solve a complex problem (Philip, 2004). Based on several expert opinions that have been described previously, it can be concluded that higher-order thinking skills are the highest skills in the process of thinking/ cognitive which is characterized by students' ability to analyze/ reasoning, evaluate, create and solve a problem based on information that has been owned correctly and efficiently and collaborative.

Learning Activity

The easiest way to find out whether or not students learn during learning process is through the learning activities shown. Learning activities are all activities carried out by students in the learning process, starting from physical activities to psychological activities (Hamalik, 2010: 171), as well as all activities carried out in the interaction process (teachers and students) in order to achieve learning goals (Hamalik (2010: 28). Learning activities studied in this paper are learning activities that are derived from learning experiences which include basic learning activities (observing, asking, trying/ collecting) and advanced learning activities in the form of 1) processing/ analyzing, 2) communicating/ dialogue, 3) discuss/ collaborate. The involvement of students in learning by doing advanced learning activities is expected to develop higher-order thinking skills/ HOTS.

\section{Method}

The development of the EXO OLO TASK uses the ADDIE development model with five continuous stages or processes starting from; 1) analysis, 2) design, 3) development, 4) implementation and 5) evaluation. While the writing of this article uses the type of conceptual idea writing that is supported by the study of related literature and its relevance to the learning model developed. This EXO OLO TASK Learning Model was developed from the Dissertation research, funded by the DRPM in the Doctoral Dissertation Research (PDD) scheme and has been published in the Scientific Journal both in regional, national and even international levels. This learning model has also been registered to the Ministry of Law and Human Rights and has received a certificate of Intellectual Property Rights (HKI).

\section{Result and Discussion}

In accordance with the title of this article, "EXO OLO TASK Learning Model: What should students do at class?" then the idea that the author came up with is to develop a learning model that prioritizes the management of learning activities using the questions as the trigger. The syntax of the learning model consists of four learning steps. The following are the four syntaxes of the learning model along with relevant theories and references. 
Table 1: The Syntax of EXO OLO TASK Learning Model and Supporting Theory

The Syntax of EXO OLO TASK Supporting Reference

Learning Model

1. Strengthening Concept

1. "Generative Learning" begins with "Process Learning" ((Slavin;1994, Jonassen;1985, Wittrock;1974, Kemp et al;1994).

2. Ormrod (2008): prior knowledge activation is the process of reminding students of the things they've already known that are related to a new topic is an effort to achieve meaningful learning.

3. Students' attention will increase through the design of special activities in the classroom (Kanfer \& Kanfer, 1991; Schunk, 2012).

2. Examination Task/EXO Task

3. Olympiad Task/OLO Task

\section{Reflection}

Oriented 1. Knowledge is built by students through the contact with the environment, challenges and materials learned (Suparno, 2013).

2. The brain works better when discussing information with others (Ruhl, Hughes dan Scholes (1987); Silbermen (2006).

Oriented 1. Question that is difficult is a way to encourage students to study as long as they are still in ZPD (Vygotsky, 1978; Sato, 2012).

2. Active participation with types of learning will encourage the achievement of learning goals such as mastery of material, understanding and the use of active knowledge (Perkins, 2006).

3. Collaboration can make the groups create better decisions because they are made based on many perspectives rather than individual decisions (Surowiecki, 2005; Janis, 1971; Leahey \& Reikowsky, 2008).

4. The advantage of collaborative learning is that the learning outcomes are better than individuals and competition (Johnson et al, 2000)

5. Social act that is experienced where students talk and communicate with each other help them to solve a problem (Gerlach, J. M., 1994 \& Laal, Laal., 2012).

6. Challenging tasks are one of the characteristics of effective learning (Silbermen, 2006).

7. Collaboration is part of 21st century learning skills, promoting communication goals, enhancing critical thinking and creativity (Uzzi \& Spiro, 2005).

8. Class dialogue is very beneficial for educators, because by monitoring their comments or questions carefully, educators can identify and resolve which can block out their ability to acquire broader knowledge and skills. (Presseisen, dkk, 1994, (dalam Ormrod, 2008)

1. Reviewing and self-assessment will help to create learning as an unforgettable activity (Silbermen, 2006).

2. Three Ways Conference (Learning Reflection). 
After describing the learning steps, then the teacher's activities and student's activities are explained in each step of learning.

Table 2: The Syntax of EXO OLO TASK Learning Model and Learning Activities

\begin{tabular}{|c|c|c|}
\hline No & $\begin{array}{c}\text { Syntax / Learning } \\
\text { Steps }\end{array}$ & Description of Learning Activities \\
\hline 1 & $\begin{array}{l}\text { Strengthening Concept } \\
\text { with Keywords } \\
\text { techniques (Concept } \\
\text { Strengthening) }\end{array}$ & $\begin{array}{l}\text { Tracing students' initial knowledge, providing reinforcement and } \\
\text { ensuring that students already have adequate initial knowledge } \\
\text { using Keyword Techniques. } \\
\text { TEACHER'S ACTIVITIES: } \\
\text { 1. Presenting key words related to the material } \\
\text { 2. Asking students to choose one keyword and then searching for } \\
\text { the meaning of keywords, relationships between keywords and } \\
\text { the relevance of keywords to the topic being studied. } \\
\text { 3. Helping students in processing information into meaningful } \\
\text { knowledge (process learning). } \\
\text { 4. Managing learning activities in the form of individual activities } \\
\text { 5. Giving reinforcement. } \\
\text { STUDENTS' ACTIVITIES: } \\
\text { 1. Looking for and read material. } \\
\text { 2. Looking for the meaning of keywords and relationships between } \\
\text { keywords. } \\
\text { 3. Presenting findings or keyword search results } \\
\text { 4. Asking for material that is not yet understood. } \\
\text { 5. Listen to the reinforcement delivered by the teacher. } \\
\text { Develop the foundation of students' higher order thinking skills } \\
\text { in the form of LOTS and MOTS. }\end{array}$ \\
\hline 2 & $\begin{array}{c}\text { EXO TASK } \\
\text { (LOT and MOTS } \\
\text { Questions) }\end{array}$ & $\begin{array}{l}\text { TEACHER'S ACTIVITIES: } \\
\text { 1. Managing learning activities in the form of paired activities. } \\
\text { 2. Providing EXO questions (C1-C3). } \\
\text { 3. Observing the learning. } \\
\text { 4. Giving space to students to transform the knowledge that has } \\
\text { been obtained in "process learning" to solve the questions } \\
\text { (generative learning). } \\
\text { 5. Providing assistance (scaffolding) as needed. } \\
\text { 6. Presenting explanations and reinforcement. }\end{array}$ \\
\hline & $\begin{array}{c}\text { Examination Oriented } \\
\text { Task }\end{array}$ & $\begin{array}{l}\text { STUDENTS' ACTIVITIES: } \\
\text { 1. Working on the questions with each pair. } \\
\text { 2. Discuss and present findings. } \\
\text { 3. Implementing generative learning. } \\
\text { 4. Asking about the questions that have not been understood (to } \\
\text { partners or other partners). } \\
\text { 5. Dialogue }\end{array}$ \\
\hline 3 & $\begin{array}{c}\text { OLO TASK } \\
\text { (HOTS Questions) }\end{array}$ & Developing Higher Order Thinking Skills/ HOTS Students. \\
\hline
\end{tabular}




\section{TEACHER'S ACTIVITIES:}

Olympiad Oriented Task

4

Refleksi

Reflection
1. Dividing students into groups (4 people/ groups).

2. Providing OLO questions (C4-C6).

3. Giving space to students to transform the knowledge that has been obtained in "process learning" to solve the questions (generative learning).

4. Observing the learning

5. Providing assistance (scaffolding) as needed.

6. Providing explanation and reinforcement.

\section{STUDENTS' ACTIVITIES:}

1. Working on questions in groups.

2. Discuss and present findings.

3. Implementing "generative learning".

4. Asking about questions that have not been understood (in groups or between groups).

5. Dialogue and collaborate

Review of self-development and reflection of learning.

\section{TEACHER'S ACTIVITIES:}

1. Facilitating students to reflect on the learning process with the 32-1 format (TWC).

2. Providing reinforcement.

\section{STUDENTS' ACTIVITIES:}

1. Presenting the results of a review of self-development and reflection on learning.

From the table above it can be seen that during the learning process, students carry out complete learning activities. As stated in the following table:

Table 3: Students' Learning Activities in Learning

\begin{tabular}{|c|c|c|c|c|}
\hline No & Syntax & Learning Activities & Information & Level \\
\hline \multirow{4}{*}{1} & \multirow{4}{*}{$\begin{array}{l}\text { Strengthening } \\
\text { Concept }\end{array}$} & Seeing and Hearing (Observing) & $\begin{array}{l}\text { Teacher } \\
\text { explanation } \\
\text { Keywords } \\
\text { displayed }\end{array}$ & LOTS \\
\hline & & Searching/ asking & $\begin{array}{l}\text { Searching for } \\
\text { keyword } \\
\text { meanings }\end{array}$ & LOTS/MOTS \\
\hline & & Recall, Recite, and Restate & $\begin{array}{l}\text { Mastering the } \\
\text { keywords }\end{array}$ & LOTS/MOTS \\
\hline & & Communicate & $\begin{array}{lr}\begin{array}{l}\text { Presenting } \\
\text { meaning } \\
\text { keywords }\end{array} & \text { of } \\
\end{array}$ & HOTS \\
\hline \multirow{3}{*}{2} & \multirow{3}{*}{ EXO TASK } & Seeing and Hearing (Observing) & $\begin{array}{l}\text { Teacher's } \\
\text { explanation }\end{array}$ & LOTS/MOTS \\
\hline & & Searching/ Processing/ Collecting & $\begin{array}{l}\text { Solution of EXO } \\
\text { questions }\end{array}$ & MOTS \\
\hline & & Discuss with partner & Solution of EXO & HOTS \\
\hline
\end{tabular}




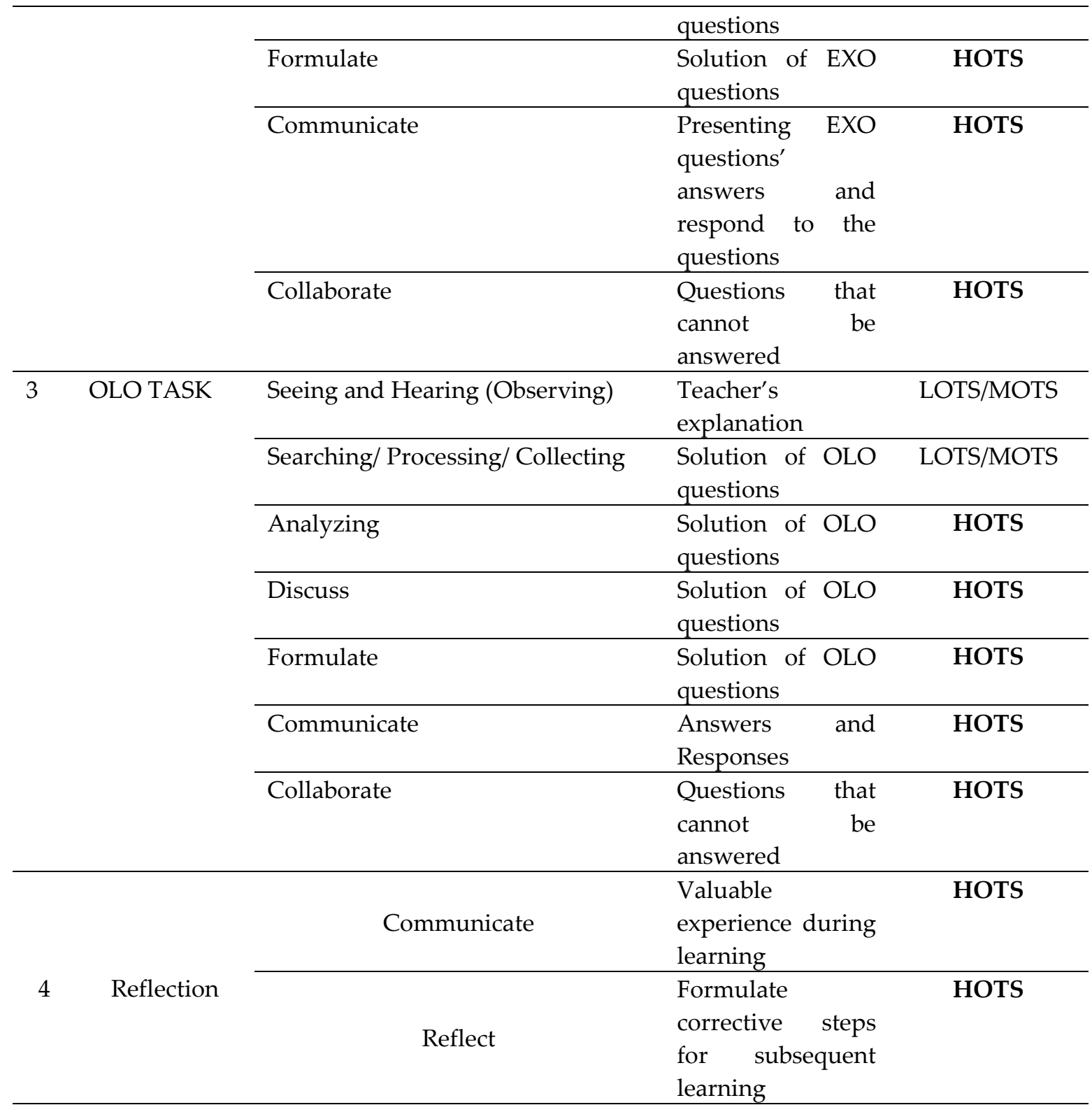

The important points that need to be addressed from the information contained in table 3 are:

1. In implementing the learning steps, students become the main actors of learning and teachers more as facilitators of learning. This condition is the implementation of constructivist learning theory in which the teacher becomes the provider of facilities to students to develop potential in an effort to process information into meaningful knowledge. In the syntax, it can be seen that "process learning" and "generative learning" are fundamental activities (Slavin; 1994, Jonassen; 1985, Wittrock; 1974, Kemp et al; 1994). Learning also demands the creativity of students both individually, in pairs and in groups to solve the questions given. Creativity is one of the important elements of 21st century learning (Bialik \& Fadel, 2015).

2. From the 19 learning activities carried out by students, 12 of them are at the level of higher-order thinking skills/ HOTS. It means that the application of the EXO OLO TASK learning model is relevant to the HOTS learning paradigm and 21st century learning framework. Not only that, the learning is also dominated by advanced learning activities or learning activities at HOTS level (Nofrion, 2018; Nofrion \& Wijayanto, 2018).

3. Dialogue, communication and collaboration activities are very dominant in each learning syntax. Especially in the OLO questions where the questions are at the HOTS level (C4-C6). Collaboration 
is an approach to overcome the more complex world development and its various problems. Variety of skills and backgrounds will meet in collaboration (Miller \& Ahmad, 2000). Collaboration can make groups make better decisions because they are based on many perspectives rather than decisions that are made individually (Surowiecki, 2005; Janis, 1971; Leahey \& Reikowsky, 2008). The advantage of collaborative learning is that achievement of learning outcomes is better than individuals and competition (Johnson et al, 2000)

Based on the explanation above, it can be seen that in learning there must be variative and creative learning activities in an effort to develop higher-order thinking skills. In the 2013 curriculum which follows the scientific approach, all the expected learning experiences are proven to be occurred in the syntax of EXO OLO TASK Learning Model. The results of the Nofrion's research in the range of years 2016 - 2018 prove that the application of the EXO OLO TASK Learning Model has been shown to improve students' learning outcomes and higher-order thinking skills. In addition, the application of this learning model is also able to improve the quality of students' learning activities both basic learning activities and advanced learning activities (Nofrion, 2018)

\section{Conclusion}

1. Current learning activity must refer to 21st century learning skills that are creativity, critical thinking, communication and collaboration.

2. The demands and challenges of the human life's development make higher-order thinking skills/ HOTS is a skill that must be developed in each learning subject.

3. Higher-order thinking skills cannot be developed if students only carry out basic learning activities (recall, recite and restate) or just observe, ask/ try, find/ collect, but they have to do more learning activities in the form of analyzing, dialogue, communicating and collaborating.

4. Challenging questions are proven to be able to trigger more quality learning activities by students.

\section{References}

Ansyar, Mohamad. 2015. Kurikulum (Hakikat, Fondasi, Desain dan Pengembangan). Jakarta. Kencana Prenadamedia Group

Aoun, J.E. (2017). Robot-proof: higher education in the age of artificial intelligence. US: MIT Press.

Bialik \& Fadel. 2015. Skill for the 21st Century;What Should Students Learn?. Centre for Curriculum Redesign. www.curriculumredesign.org

Brandt, Ronald D \& Tyler, Ralph W. 2007. Goals and Objectives In Contemporary Issues in Curriculum. Allan C. Orsnstein, Edward F Pajak, \& Stacy B Ornstein (Eds). Boston;Pearson Education, Inc, 6-12

Gredler, E. 2011. Learning and Instruction: Teori dan Aplikasi (Edisi Keenam). Kencana Prenada Media Group: Jakarta.

Hamalik, Omar. 2010. Strategi Belajar Mengajar. Bumi Aksara: Jakarta

Johnson, D., Johnson, R., \& Stanne, M. (2000). Cooperative learning methods: A meta-analysis

Miller, C., \& Ahmad, Y. (2000). Collaboration and partnership: an effective response to complexity and fragmentation or solution built on sand? International Journal of Sociology and Social Policy, 20(5/6), 1-38.

N Nofrion et al. 2018. IOP Conf. Ser.: Earth Environ. Sci.145 012038

Nofrion, N; Wijayanto, Bayu. Learning Activities In Higher Order Thinking Skill (HOTS) Oriented Learning Context. Geosfera Indonesia, [S.1.], v. 3, n. 2, p. 122-130, aug. 2018. ISSN 2614-8528.

Nofrion, N. (2018, October 14). Panduan Pelaksanaan Model Pembelajaran Exo Olo Task (Mengembangkan Keterampilan Berpikir Tingkat Tinggi (HOTS) Dalam Pembelajaran). https://doi.org/10.31227/osf.io/wh2mp

Ornstein, Allan C \& Hunkins, Francis, P. 2013. Curriculum; Foundation, Principles and Issues. Boston;Pearson 
Perkins, D. (2006). Constructivism and troublesome knowledge. Overcoming barriers to student understanding: Threshold concepts and troublesome knowledge, 33-47.

Philips, R. W. 2004. Skinner's Science Of Dental Material. 9th ed. Philadelphia : W.B. Saunders Co.

Richey et al. 2011. The Instructional Design Knowledge Base; Theory, Research and Practise. New York;Routledge

Slavin, Robert E. 1994. Educational Psychology:Theory and Practice. Boston:Allyn and Bacon

Schunk, Dale H. 2012. Learning Theories: An Educational Perspective, Fifth Edition. New Jersey:Pearson Prentice Hall

Surowiecki, J. (2005). The wisdom of crowds. Anchor Books: USA

Uzzi, B., \& Spiro, J. (2005). Collaboration and creativity: The small world Problem1. American Journal of Sociology, 111(2), 447-504 